\title{
IMMUNE, REPRODUCTIVE, AND CYTOGENETIC
}

\section{CHANGES AMONG WASTE INCINERATION WORKERS AT THE COMPOST FERTILIZER PLANT IN ZAGAZIG CITY}

\author{
By \\ El-Laithy N.; Abbas R.A.; Sabik L.M.*; El-Hawary A.; \\ El-Sebaey A.** and Eassa M.** \\ FROM \\ Departments of Community, Environmental, and Occupational Medicine, \\ Forensic Medicine and Clinical Toxicology*, and Clinical Pathology**. \\ Faculty of Medicine, Zagazig University.
}

\begin{abstract}
Background: The adverse health effects associated with mass burn incineration are of great concern as large population groups and workers may be exposed to derived toxic substances. Objectives: 1) determining some of the immunological, reproductive, and cytogenetic changes among workers exposed to waste incineration emissions at the waste incineration area of the compost fertilizer plant in Zagazig City, 2) determining the blood lead levels of the studied workers, and 3) assessing airborne particulate matter concentrations at the open dump and waste incineration area. Subjects and methods: This comparative cross-sectional study was conducted on 42 waste incineration workers, who were exposed to waste incineration emissions at the compost fertilizer plant in Zagazig City and a non-exposed control group (51 workers from 2 sweet factories). All workers were subjected to questionnaires, clinical examinations, and laboratory investigations, that included blood lead levels estimation, immunoglobulins estimation, flow cytometric analysis, and conventional cytogenetic
\end{abstract}


analysis; While, only 12 workers from both groups agreed to perform semen analysis. Also, sampling of respirable airborne particulates, at the open dump and waste incineration area, was done. Results: Significantly higher percent of waste incineration workers had past history of recurrent infections suggesting depressed immune response compared to the controls. Also, married waste incineration workers had significantly higher complaints from secondary infertility, decreased libido, and congenital anomalies in their children compared to the married controls. Immunoglobulins and flow cytometric results demonstrated a significant increase in both $\mathrm{CD}_{8}$ and $\mathrm{CD}_{25}+$ cells $(\mathrm{P}<0.05)$ and a significant decrease in $\mathrm{CD}_{4} / \mathrm{CD}_{8}$ ratio $(\mathrm{P}<0.05)$ among waste incineration workers compared to the control group; while there were no significant differences detected regarding immunoglobulins profile, $\mathrm{CD}_{3}$, and $\mathrm{CD}_{4}$. The results of semen analysis illustrated that, waste incineration workers had a significant decrease in the total sperm count and sperm motility and a significant increase in the percentage of abnormal forms of sperms than did the controls. The conventional cytogenetic analysis of this study revealed significantly higher frequency of chromosomal aberrations (dicentric chromosomes and accentric fragment) among waste incineration workers compared to the controls $(\mathrm{P}<0.001)$. Moreover, waste incineration workers with chromosomal aberrations had significantly longer duration of employment than those without chromosomal aberrations $(\mathrm{P}<0.05)$; while, smoking had no significant effect on the results of their cytogenetic analysis. Waste incineration workers were found to have significantly higher blood lead levels $(11.8+3.4 \mu \mathrm{g} / \mathrm{dl})$ when compared to the controls $(7.8 \pm 1.85 \mu \mathrm{g} / \mathrm{dl})(\mathrm{P}<0.001)$. Finally, the average concentration of the respirable particulate matter in the open dump and waste incineration area was $0.47 \mathrm{mg} / \mathrm{m}^{3}$, which exceeds its threshold limit value (TLV). Conclusion and recommendations: unprotected occupational exposure to waste incineration emissions can cause serious immunological, reproductive, and cytogentic changes. So, a well designed control program is recommended, which should include; avoiding open burning of waste products and promote the use of non- incineration treatment technologies, using incinerators equipped with proper emission control system, continuous environmental and biological monitoring for lead, particulate matter, and other hazardous materials, using immune system parameters, semen quality, and chromosomal aberrations as biomarkers of effect in such workers, and using suitable protective equipment during work. 


\section{Introduction}

Municipal solid waste incineration is an integrated waste management system, which offers a reduction in both the mass and volume of waste subjected to final disposal ${ }^{(1)}$. Incinerators are typically fed with mixed waste containing substances such as heavy metals and chlorinated organic chemicals. These substances can assume other forms during incineration that are likely to be more toxic than the original compounds ${ }^{(2)}$. Moreover, incineration as a method of waste disposal cannot destroy all organic constituents of hazardous waste without dangerous emission of numerous toxic chemicals into the atmosphere as dioxins, polycyclic aromatic hydrocarbons (PAHs) ${ }^{(2,3,4)}$, fine particulate matter, hydrogen halide gases, metal aerosols, and other toxic materials ${ }^{(5)}$. Many of these chemicals are known to be persistent, bioaccumulative, and carcinogenic or endocrine disruptors ${ }^{(6)}$.

Chemical analysis of gaseous release of waste incineration sites revealed more than 400 compounds, most of them arising by degradation inside the tip. The main compounds are methane and carbon dioxide, but substances with known or suspected carcinogenic potential as PAHs and dioxins are also found ${ }^{(7,8)}$. Generally, owing to the variable composition of the mixture, the toxicological evaluation is difficult ${ }^{(9)}$.

Inhalation of these gaseous and particulate release of waste tips may bear a potential risk to workers and possibly to residents surrounding these waste disposal sites; however occupational exposure is of higher intensity compared to environmental exposure ${ }^{(2,10)}$. So, many adverse heath effects from occupational exposure to these hazardous waste and their incineration products may occur; such as asthma and respiratory hyper-responsiveness, neurological diseases, reproductive health problems, immunological and endocrinal diseases, and cancer including leukemia ${ }^{(6)}$.

So, this study was conducted to; 1) determine some of the immunological, reproductive, and cytogenetic changes among workers exposed to waste incineration emissions at the waste incineration area of the compost fertilizer plant in Zagazig City, 2) determine the blood lead levels of the studied workers, and 3) assess airborne particulate matter concentrations at the open dump and waste incineration area.

\section{Subjects and Methods}

\section{Study design and setting:}

This comparative cross-sectional study was conducted from January to June 2006 at the compost fertilizer plant, which has 
been set inside Zagazig City since the year 1995. The plant occupies 4 feddans with a total manpower of 58 workers and employees. This plant comprises the following sections:

1-The administration building: it includes rooms for administrative employees and technicians.

2-Open dump and waste incineration area: the open dump area receives about 250 tons of municipal solid waste per day, collected from Zagazig City. The solid waste passes along a moving belt; where opening of the waste bags takes place by the workers. Then, at the end of the belt, separation of organic waste occurs through sieves to be accumulated in the ground. The rest of the main waste bulk passes through multiple toothed rotatory cylinder to separate the adhesive parts. Then, the waste passes along another belt in order to collect some waste products for reuse again as glass parts, iron parts, and papers. Finally, the waste products pass along a second sieve to separate the accumulated organic waste to be collected in the ground. The remaining of the waste products is incinerated openly at the waste incineration area beside the open dump area.

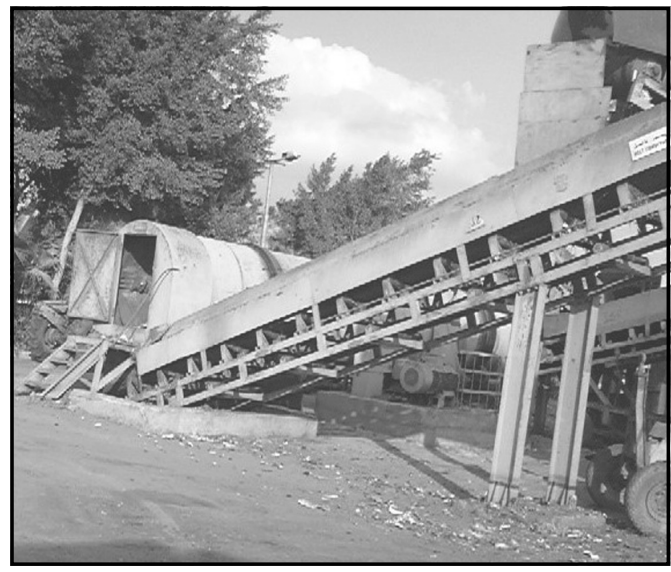

Figure (1): One of the moving belts used in transporting the waste to sieves.

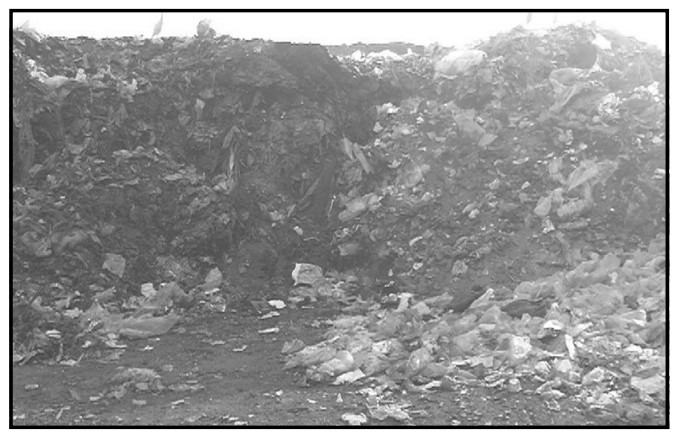

Figure (2): The open dump and waste incineration area at the compost fertilizer plant.

3-Waste processing area, which includes:

A-Fermentation area: where the collected organic waste products are transported to this area to form compost fertilizer by aerobic decomposition.

B-Fine line area: after complete fermentation of the waste, the compost fertilizer passes through sieves to separate the 
fine fertilizer to be packed and used; while the coarse parts are refusable.

\section{System of work at the plant:}

- The total number of workers in this plant is 48 workers [ 40 workers ( 38 males $\& 2$ females) and 8 supervisors] and 4 technicians. They work for 5 hours daily, starting from $8 \mathrm{AM}$ to $6 \mathrm{PM}$ in two daily shifts for 6 days per week. The shifts are:

1- Morning shift: starts from $8 \mathrm{AM}$ to 1 PM.

2- Afternoon shift: starts from 1 PM to 6 PM.

- The administrative employees $(\mathrm{N}=6)$ work for 6 hours daily, from 8.30 AM to $2.30 \mathrm{PM}$.

- Nearly all workers didn't use protective measures except few workers were wearing boots.

\section{Study population:}

* Exposed group: 42 male workers were selected and included in this study according to the following inclusion criteria:

1- Regular and direct exposure to waste incineration emissions.

2- Apparently healthy.

3- Agree to participate in this study.
* Control group: 51 workers from two sweet factories in Zagazig City were included in this study according to the following inclusion criteria:

1- Not occupationally exposed to waste incineration emissions.

2- Apparently healthy.

3- Agree to participate in this study.

4- Comparable to the exposed group regarding age, sex, residence, socioeconomic standard, smoking habit, and duration of work.

* Exclusion criteria for both of the studied groups were $(11,12)$ :

1-Current infections or cancer (at the time of the study).

2-History of cortisone therapy or any immune suppressive therapy.

3- History of epididymoorchitis, bilateral inguinal herniotomy, varicocelectomy, and trauma to the testis.

4- Exposure to ionizing radiation in the last six months.

So, 6 exposed workers ( 4 males \& 2 females) were excluded from the study.

Ethical considerations:

-Permissions were obtained from the managers of the plant. 
-Informed consents were obtained from all the participants.

\section{Methods:}

1-Questionnaire: a pre-designed questionnaire was used with each participant, which included:

A-Personal history: it included age, residence, marital status, number of children, and some relevant habits such as; smoking habit, substance abuse, eating balanced diet, and excess eating grilled and smoked food $(11,12)$

B-Occupational history: it included current job, hours of work per day, duration of employment in years, previous or another jobs in which there was exposure to another pollutants as fly ash (from burning of coal, rice, or maize), solvents, pesticides, heavy metals, and silica ${ }^{(11)}$.

C-Home environmental data; such as residing near waste disposal area, incinerator, or foundry as well as the type of fuel used for cooking and heating.

D-Present and past history: they included questions suggesting depressed immune response as recurrent infections, cancer, chemotherapy, or cortisone therapy.
History of exposure to ionizing radiation was also taken. Moreover, history suggestive of reproductive disorders ${ }^{(7)}$ as secondary infertility, decreased libido, and past history of congenital anomalies in their children was also taken.

2-Clinical examination: general and local examinations of all participants were carried out to detect the presence of current infections.

\section{3-Laboratory investigations:}

*Samples collection:

A sample of venous blood was withdrawn from each worker under complete aseptic conditions. Moreover, semen samples from 7 waste incineration workers and 5 controls (the other workers refused to give semen samples) were obtained by masturbation into sterile containers; where workers were instructed to avoid any sexual activity for at least 3 to 4 days before taking the samples.

A-Blood lead level estimation: $5 \mathrm{ml}$ blood were put into tubes containing heparin and stored at 40C for estimation of blood lead level. Blood lead level was determined using Atomic Absorption Spectrophotometer (Buck Scientific Model 210VGP) at the Central Laboratory of the Faculty of Veterinary Medicine. Lead level was read at a wave length $283.3 \mathrm{~nm}^{(13)}$. 


\section{B-Estimation of immunoglobulins: 2} $\mathrm{ml}$ blood were added into plain tubes to obtain serum for immunoglobulins (Igs) estimation using BN-Prospec (Dade Behring) Germany. An immunochemical reaction was used; where immunoglobulins in serum form complexes with specific antibodies. These complexes scatter a beam of light passing through the reaction. The intensity of the scattered light is proportional to the concentration of Ig in the sample. The intra and inter-assay $\mathrm{CV}$ for $\mathrm{IgG}$ are $2.1 \%$ and $2.7 \%$, respectively; while, intra and inter-assay $\mathrm{CV}$ for $\mathrm{IgM}$ are $2.7 \%$ and $1.9 \%$, respectively ${ }^{(14)}$.

C-Flow cytometric analysis: $2 \mathrm{ml}$ blood were put into EDTA containing tubes for flow cytometric analysis (15). The expression of $\mathrm{CD}_{3}, \mathrm{CD}_{4}, \mathrm{CD}_{8}$, and $\mathrm{CD}_{25}$ on peripheral blood lymphocytes were analyzed using Flow Cytometer (Facscan $\mathrm{BD}$, San Jose, $\mathrm{CA}) . \mathrm{CD}_{3}, \mathrm{CD}_{4}$, and $\mathrm{CD}_{25}$ were labeled by F I TC; while $\mathrm{CD}_{8}$ was labeled by PE ( BD, San Jose) :

-Lymphocytes were separated by Ficoll and concentrated in PBS in order to give concentration of $1 \mu 10^{6}$ cell / $\mathrm{ml}$.

-In three labeled tubes $50 \mu \mathrm{l}$ of separated lymphocytes $(1 \mu 106$ cell / ml) were added to $10 \mu \mathrm{l}$ from each monoclonal antibody. Another tube was used as negative control using irrelevant iso- tope matched mAbs (IgG1a) labeled by F I TC, IgG2a labeled by PE, then incubated for 20 minutes at room temperature.

-RBCs were lysed using $1 \mathrm{ml}$ of lysing solution $(1 \mu 10)$ and centrifuged for 10 minutes at $1200 \mathrm{rpm}$.

-The supernatant was discarded and cells were washed twice by PBS and the pellet was resuspended finally in $0.5 \mathrm{ml}$ PBS.

-Data on at least 10.000 cells were collected using Facscan Flow Cytometry and analyzed using Cell Quest soft ware (BD).

-The results were interpreted as percent of total gated cells (lymphocytes).

D-Cytogenetic analysis: $2 \mathrm{ml}$ blood were added into tubes containing lithium heparin "preservative free" for cytogenetic analysis. The conventional cytogenetic analysis using Giemsa stain was used ${ }^{(16)}$. This was done through:

-Peripheral blood lymphocytes culture: Preparation of media: under laminar air flow, a $100 \mathrm{ml}$ bottle of RBMI 1640 (with L-glutamine) media "GIB COUSA", were added to $20 \mathrm{ml}$ FCS "GIB CO-USA" \& 5ml phytohema-gglutinine "biochrome AG" and $1.5 \mathrm{ml}$ penicillin / streptomycin $(5000 \mu / \mathrm{ml})$.This prepared 
media was divided into sterile falcon tubes, about $7 \mathrm{ml}$ in each one and kept in freezer, when to be used they were thawed by putting at $37{ }^{\circ} \mathrm{C}$ water bath $1 / 2$ hour before adding blood. The volume of heparinised blood added to each tube was adjusted according to total leucocytic count "final concentration of cells is $1 \mu 10^{6}$ cells $/ \mathrm{ml}$ prepared media". After inoculation of blood, the tubes were inverted for good mixing then incubated at $37{ }^{\circ} \mathrm{C}$ for 72 hours.

\section{-Harvesting of cultured cells: Cells} were arrested in metaphase by colcemid $(10 \mu \mathrm{g} / \mathrm{ml})$ "Euro-lone USA", $150 \mu \mathrm{l}$ were added to each tube for 2 hours at $37^{\circ} \mathrm{C}$. Cells were swelled by warm hypotonic solution (kcl 5.95 g/l)," Winlab, England". Then the cells were fixed by fresh cold fixative solution composed of 3 parts analytic grade methanol, "Riedel, Germany" and one part reagent grade acetic acid (Fulka, Germany). Each tube was washed by cold fix 3 times and cells were dropped into cold wet clean glass slide and stained by Giemsa stain "G-bending". 500 metaphases were examined for each case by Olympus light microscope under oil emersion lens to determine chromosomal aberrations.

E-Semen analysis: semen specimens were examined within 1 hour macroscopi- cally and microscopically for volume, sperm count, sperm motility, and abnormal forms ${ }^{(17)}$.

4-Environmental assessment: sampling of particulate matter, emitted from open incineration of waste at the waste incineration area, was performed using Dust Track Aerosol Monitor 8520. It gives the average of readings in $\mathrm{mg} / \mathrm{m}^{3}$ for the respirable particles (with a cut size of $10 \mu \mathrm{m}$ ) suspended in air at flow rate adjusted at $1.7 \mathrm{~L} / \mathrm{min}$.

*Statistical Analysis: It was performed using SPSS (Statistical Package for Special Sciences) program for windows (version 9.0) ${ }^{(18)}$. The significance of difference between the study variables was evaluated using chi- squared $\left(\chi^{2}\right)$ and Fisher exact tests for qualitative data and student's t-test for quantitative data. The significance level was considered at Pvalue $<0.05$.

\section{Results}

Table (1) shows that, absence of statistical significant differences between waste incineration workers and the controls regarding age, marital status, smoking habit and the pack years of smoking, residence, fuel used in cooking and heating, and duration of work. Moreover, none of the studied workers had history of substance 
abuse, or eat balanced diet or excess grilled or smoked food. Also, none of them used suitable protective measures during work or had previous or other job requiring exposure to fly ash (from burning of coal, rice, or maize), solvents, pesticides, heavy metals, and silica.

Table (2) illustrates that, significantly higher percent of waste incineration workers had past history of recurrent infections as throat infections $(14.3 \%)$, chest infections $(26.2 \%)$, and fungus infections (16.7\%) compared to the controls $(1.96 \%$, $5.9 \%$, and $3.9 \%$, respectively). Also, married waste incineration workers had significantly higher complaints from secondary infertility, decreased libido, and congenital anomalies in their children compared to the married controls $(\mathrm{P}<0.05)$.

Table (3) demonstrates that, the average concentration of the respirable particulate matter in the open dump and waste incineration area was $0.47 \mathrm{mg} / \mathrm{m}^{3}$.

Table (4) illustrates that, waste incineration workers had significantly higher blood lead levels $(11.8 \pm 3.4 \mu \mathrm{g} / \mathrm{dl})$ compared to the controls $(7.8 \pm 1.85 \mu \mathrm{g} / \mathrm{dl})(\mathrm{P}$ $<0.001)$.

Table (5) shows that, there were no statistical significant differences between waste incineration workers and the con- trols regarding $\operatorname{IgM}$ and $\operatorname{IgG}(\mathrm{P}>0.05)$. As regards the flow cytometric results, there was significant increase $(\mathrm{P}<0.05)$ in both $\mathrm{CD}_{8}+$ and $\mathrm{CD}_{25}+$ cells $(31.33 \pm 9.69$ and $28.17+6.7$, respectively) among waste incineration workers compared to the controls $(28.22+3.53$ and $25.21+7.09$, respectively) and a significant decrease $(\mathrm{P}<0.05)$ in $\mathrm{CD}_{4} / \mathrm{CD}_{8}$ ratio $(0.99 \pm 0.22)$ among waste incineration workers compared to the controls $(1.09 \pm 0.15)$. Otherwise, there were no statistical significant differences between waste incineration workers and the controls regarding $\mathrm{CD}_{3}$ and $\mathrm{CD}_{4}+$ cells $(\mathrm{P}>0.05)$.

Table (6) demonstrates that, the examined waste incineration workers had significant decrease in the total sperm count $(39.33 \pm 11.5)$ and sperm motility (36.17 \pm 9.7) and a significant increase in the percentage of the abnormal forms of sperms $(51.16 \pm 15.1)$ than did the controls $(69.83$ $\pm 19.35,66.41 \pm 16.27$, and $32.67 \pm 8.9$, respectively).While there was no significant difference between both groups regarding the volume of semen $(\mathrm{P}>0.05)$.

Table (7) demonstrates the results of cytogenetic analysis; where waste incineration workers had significantly higher frequency of chromosomal aberrations (dicentric chromosomes (Fig. 3) and accentric fragment) $(3.14 \pm 0.2$ and $1.6 \pm$ 
0.36 , respectively) compared to the controls $(2.91 \pm 0.16$ and $1.18 \pm 0.17$, respectively) $(\mathrm{P}<0.001)$.

Table (8) shows that, smoking had no significant effect on the results of cytogenetic analysis of waste incineration work- ers $(\mathrm{P}>0.05)$. On the other hand, workers with chromosomal aberrations had significantly longer duration of employment (9.6 $\pm 0.37)$ when compared to those without chromosomal aberrations $(8.4 \pm 0.97)$ $(\mathrm{P}<0.05)$.

Table (1): Relevant Socio-demographic characteristics, habits, home environmental and occupational data of the studied groups.

\begin{tabular}{|c|c|c|c|c|}
\hline Relevant characteristics & & $\begin{array}{c}\text { Waste incineration } \\
\text { workers } \mathrm{N}=42\end{array}$ & $\begin{array}{l}\text { Control group } \\
\qquad \mathrm{N}=51\end{array}$ & P- value \\
\hline Age (Y) & $(\bar{X}+\mathrm{SD})$ & $39.1 \pm 4.4$ & $38.3 \pm 5.9$ & $>0.05$ \\
\hline \multicolumn{5}{|l|}{ Marital status } \\
\hline Married & $\mathrm{N}(\%)$ & $37(88.1 \%)$ & $43(84.3 \%)$ & $>0.05$ \\
\hline Single & $\mathrm{N}(\%)$ & $5(11.9 \%)$ & $8(15.7 \%)$ & \\
\hline Smokers & $\mathrm{N}(\%)$ & $26(61.9 \%)$ & $28(54.9 \%)$ & $>0.05$ \\
\hline Pack years & $(\overline{\mathrm{X}}+\mathrm{SD})$ & $8.7 \pm 1.2$ & $9.1 \pm 1.1$ & $>0.05$ \\
\hline \multicolumn{5}{|l|}{ Residence } \\
\hline Urban & $\mathrm{N}(\%)$ & $14(33.3 \%)$ & $23(45.1 \%)$ & $>0.05$ \\
\hline Rural & $\mathrm{N}(\%)$ & $28(66.7 \%)$ & $28(54.9 \%)$ & \\
\hline Residence near a source of pollution & $\mathrm{N}(\%)$ & $12(28.6 \%)$ & $17(33.3 \%)$ & $>0.05$ \\
\hline \multicolumn{5}{|l|}{ Fuel used in cooking $\&$ heating } \\
\hline Wood or coal & $\mathrm{N}(\%)$ & $13(30.9 \%)$ & $19(37.3 \%)$ & $>0.05$ \\
\hline Kerosene & $\mathrm{N}(\%)$ & $19(45.2 \%)$ & $23(45.1 \%)$ & \\
\hline Duration of work & $(\overline{\mathrm{X}}+\mathrm{SD})$ & $9.6 \pm 1.02$ & $10.1 \pm 2.1$ & $>0.05$ \\
\hline
\end{tabular}

NB: None of the studied workers had history of substance abuse, or eat balanced diet or excess grilled or smoked food. Moreover, none of them used suitable protective measures during work or had previous or other job requiring exposure to fly ash (from burning of coal, rice, or maize), solvents, pesticides, heavy metals, and silica. 
Table (2): Distribution of the studied workers regarding past and present history of relevant health problems.

\begin{tabular}{|c|c|c|c|c|}
\hline \multicolumn{2}{|l|}{ Relevant health problems } & $\begin{array}{c}\text { Waste incineration } \\
\text { workers } \mathrm{N}=42\end{array}$ & $\begin{array}{l}\text { Control group } \\
\qquad \mathrm{N}=51\end{array}$ & P-value \\
\hline \multicolumn{5}{|c|}{ Past history of recurrent infections } \\
\hline Throat infections & $\mathrm{N}(\%)$ & $6(14.3 \%)$ & $1(1.96 \%)$ & $<0.05$ \\
\hline Chest infections & $\mathrm{N}(\%)$ & $11(26.2 \%)$ & $3(5.9 \%)$ & $<0.01$ \\
\hline Fungus infections & $\mathrm{N}(\%)$ & $7(16.7 \%)$ & $2(3.9 \%)$ & $<0.05$ \\
\hline \multicolumn{5}{|c|}{ History of reproductive disorders $*$} \\
\hline Secondary infertility & $\mathrm{N}(\%)$ & $7(18.9 \%)$ & $1(2.3 \%)$ & $<0.05$ \\
\hline Decreased libido & $\mathrm{N}(\%)$ & $18(48.6 \%)$ & $11(25.6 \%)$ & $<0.05$ \\
\hline Congenital anomalies & $\mathrm{n} N(\%)$ & $8(21.6 \%)$ & $2(4.7 \%)$ & $<0.05$ \\
\hline
\end{tabular}

NB:* Married waste incineration workers $(\mathrm{N}=37)$ and married control group $(\mathrm{N}=43)$.

Table (3): The average concentration of respirable particulates at the waste incineration area.

\begin{tabular}{|c|c|}
\hline $\begin{array}{c}\text { Average concentration of respirable particulates } \\
\left(\mathrm{mg} / \mathrm{m}^{3}\right)\end{array}$ & $\begin{array}{c}\text { Threshold limit value (TLV) } \\
\left(\mathrm{mg} / \mathrm{m}^{3}\right)\end{array}$ \\
\hline 0.47 & $<0.1$ \\
\hline
\end{tabular}

Table (4): Blood lead levels among the studied groups.

\begin{tabular}{|l|c|c|c|c|}
\hline & Waste incineration workers & Control group & \multirow{2}{*}{ t-test } & P-value \\
& $\mathrm{N}=42$ & $\mathrm{~N}=51$ & & \\
\cline { 2 - 3 } & $\mathrm{X} \pm \mathrm{SD}$ & $\mathrm{X} \pm \mathrm{SD}$ & & \\
\hline Blood lead level $(\mu \mathrm{g} / \mathrm{dl})$ & $11.8 \pm 3.4$ & $7.8 \pm 1.85$ & 7.2 & $<0.001$ \\
\hline
\end{tabular}


Table (5): Immunoglobulins profile and flow cytometric results of the studied groups.

\begin{tabular}{|c|c|c|c|c|}
\hline $\begin{array}{c}\text { Some immune } \\
\text { system parameters }\end{array}$ & $\begin{array}{c}\text { Waste incineration } \\
\text { workers } \\
\mathrm{N}=42 \\
\end{array}$ & $\begin{array}{l}\text { Control group } \\
\qquad \mathrm{N}=51\end{array}$ & t-test & P-value \\
\hline & $\overline{\mathrm{X}} \pm \mathrm{SD}$ & $\overline{\mathrm{X}} \pm \mathrm{SD}$ & & \\
\hline $\operatorname{IgM}(\mathrm{g} / \mathrm{ml})$ & $2.11 \pm 0.85$ & $2.31 \pm 0.85$ & 1.1 & $>0.05$ \\
\hline $\operatorname{IgG}(\mathrm{g} / \mathrm{ml})$ & $7.56 \pm 1.97$ & $8.09 \pm 1.91$ & 1.3 & $>0.05$ \\
\hline $\mathrm{CD}_{3} \%$ & $62.98 \pm 8.10$ & $64.18 \pm 7.77$ & 0.7 & $>0.05$ \\
\hline $\mathrm{CD}_{4} \%$ & $29.89 \pm 5.93$ & $31.02 \pm 5.02$ & 0.9 & $>0.05$ \\
\hline $\mathrm{CD}_{8} \%$ & $31.33 \pm 9.69$ & $28.22 \pm 3.53$ & 2.1 & $<0.05$ \\
\hline $\mathrm{CD}_{4} / \mathrm{CD}_{8}$ ratio & $0.99 \pm 0.22$ & $1.09 \pm 0.15$ & 2.6 & $<0.05$ \\
\hline $\mathrm{CD}_{25} \%$ & $28.17 \pm 6.7$ & $25.21 \pm 7.09$ & 2.1 & $<0.05$ \\
\hline
\end{tabular}

Table (6): Semen analysis of the examined groups of workers.

\begin{tabular}{|l|c|c|c|c|}
\hline \multicolumn{1}{|c|}{$\begin{array}{c}\text { Semen analysis } \\
\text { results }\end{array}$} & $\begin{array}{c}\text { Waste incineration } \\
\text { workers } \\
\mathrm{N}=7\end{array}$ & Control group & t-test & P-value \\
\cline { 2 - 4 } & $\overline{\mathrm{X}} \pm \mathrm{SD}$ & $\mathrm{N}=5$ & & \\
\hline Semen volume $(\mathrm{ml})$ & $2.42 \pm 0.32$ & $2.28 \pm 0.31$ & 0.75 & $>0.05$ \\
\hline Total sperm count $(\mathrm{x} 106 / \mathrm{ml})$ & $39.33 \pm 11.5$ & $69.83 \pm 19.35$ & 3.4 & $<0.01$ \\
\hline Sperm motility & $36.17 \pm 9.7$ & $66.41 \pm 16.27$ & 4.1 & $<0.01$ \\
\hline Abnormal forms $(\%)$ & $51.16 \pm 15.1$ & $32.67 \pm 8.9$ & 2.4 & $<0.001$ \\
\hline
\end{tabular}

Table (7): Cytogenetic analysis for the studied groups.

\begin{tabular}{|l|c|c|c|c|}
\hline \multicolumn{1}{|c|}{$\begin{array}{c}\text { Cytogenetic analysis } \\
\text { results }\end{array}$} & $\begin{array}{c}\text { Waste incineration } \\
\text { workers } \\
\mathrm{N}=42\end{array}$ & Control group & t-test & P-value \\
\cline { 2 - 5 } & $\overline{\mathrm{X}} \pm \mathrm{SD}$ & $\overline{\mathrm{X}} \pm \mathrm{SD}$ & & \\
\hline $\begin{array}{l}\text { Dicentric chromosomes (dic) } \\
\text { / 500 cell }\end{array}$ & $3.14 \pm 0.20$ & $2.91 \pm 0.16$ & 6.2 & $<0.001$ \\
\hline $\begin{array}{l}\text { Accentric fragment (ace ) / } \\
500 \text { cell }\end{array}$ & $1.6 \pm 0.36$ & $1.18 \pm 0.17$ & 7.4 & $<0.001$ \\
\hline
\end{tabular}




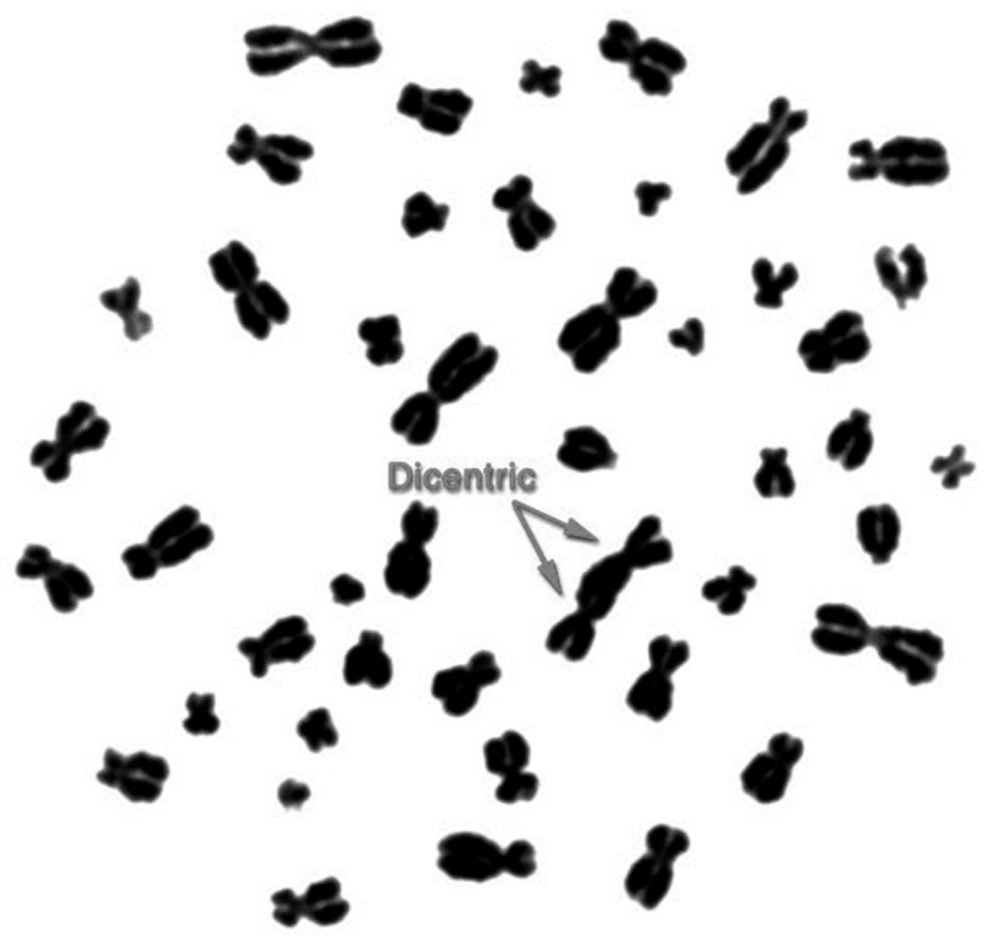

Figure (3): A metaphase of a waste incineration worker aged 38 years showing a dicentric chromosome.

Table (8): Effect of smoking and duration of work on cytogentic analysis results among waste incineration workers

\begin{tabular}{|c|c|c|c|c|}
\hline Variable & $\begin{array}{l}\text { Workers with chro- } \\
\text { mosomal aberrations } \\
\qquad \mathrm{N}=7\end{array}$ & $\begin{array}{l}\text { Workers without chro- } \\
\text { mosomal aberrations } \\
\qquad \mathrm{N}=35\end{array}$ & $\begin{array}{c}\text { Test of } \\
\text { significance }\end{array}$ & P-value \\
\hline $\begin{array}{rr}\text { Smokers } & (\mathrm{N}=26) \\
& \mathrm{N}(\%)\end{array}$ & $4(57.1 \%)$ & $22(62.9 \%)$ & Fisher exact & $>0.05$ \\
\hline $\begin{array}{r}\text { Duration of work (Y) } \\
(\bar{X}+\mathrm{SD})\end{array}$ & $9.6 \pm 0.37$ & $8.4 \pm 0.97$ & $\mathrm{t}=2.4$ & $<0.05$ \\
\hline
\end{tabular}




\section{Discussion}

Waste incineration releases various environmental chemical pollutants containing heavy metals, dioxins, PAHs, polychlorinated dibenzo-furans (PCDFs), and other organic materials. Many of these pollutants have been found to cause various health effects ${ }^{(19,20,21)}$. So, this study was conducted to; 1) determine some of the immunological, reproductive, and cytogenetic changes among workers exposed to waste incineration emissions at the waste incineration area of the compost fertilizer plant in Zagazig City, 2) determine the blood lead levels of the studied workers, and 3) assess airborne particulate matter concentrations at the open dump and waste incineration area.

In the present study, significantly higher percent of waste incineration workers had past history of recurrent infections as throat infections $(14.3 \%)$, chest infections (26.2\%), and fungus infections (16.7\%) compared to the controls $(1.96 \%$, $5.9 \%$, and $3.9 \%$, respectively) suggesting depressed immune response. Also, married waste incineration workers had significantly higher complaints from secondary infertility, decreased libido, and congenital anomalies in their children compared to the married controls $(\mathrm{P}<0.05)$ suggesting reproductive health affection. In accor- dance with the results of this study, many researchers reported that, inhalation of gaseous and particulate release of waste incineration may bear a potential risk to the workers, with the development of adverse heath effects especially immunological and reproductive health problems ${ }^{(2,6)}$.

As most metals and toxic compounds emitted during waste incineration are adsorbed to particulate matter ${ }^{(22)}$. So in the present study, the average concentration of the respirable particulate matter in the open dump and waste incineration area was measured and found to be $0.47 \mathrm{mg} /$ $\mathrm{m} 3$, which exceeds its threshold limit value $(<0.1 \mathrm{mg} / \mathrm{m} 3)^{(23)}$. This is in agreement with the result of a similar study, in which high concentration of particulate matter from waste incineration due to incomplete combustion was recorded ${ }^{(22)}$.

As, lead is the heavy metal that usually reaches higher concentrations than any other metals during waste incineration ${ }^{(22,24)}$; moreover, it has been identified as a genotoxic ${ }^{(25)}$, an immunotoxic ${ }^{(11)}$, and a reproductive hazard ${ }^{(26)}$. So, blood lead levels were measured for the studied workers; where waste incineration workers had significantly higher blood lead levels $(11.8 \pm 3.4 \mu \mathrm{g} / \mathrm{dl})$ compared to the controls $(7.8 \pm 1.85 \mu \mathrm{g} / \mathrm{dl})(\mathrm{P}<0.001)$. This is in consistent with the result of a similar 
study, in which significantly higher blood lead levels were revealed among waste incineration workers $(11.0 \mu \mathrm{g} / \mathrm{dl})$ compared to that of the control $(7.4 \mu \mathrm{g} / \mathrm{dl}){ }^{(27)}$; where it was attributed to the bioavailability of lead in the municipal ash, high exposure to lead during cleaning process, and not using protective devices during work. However, in both studies, blood lead level didn't exceed the biological exposure limit (BEL) of lead $(40 \mu \mathrm{g} / \mathrm{dl})$ recommended by the Occupational Safety and Health Administration (OSHA) ${ }^{(28)}$. However, blood lead levels as low as 5 to $15 \mu \mathrm{g} / \mathrm{dl}$ were considered risky and have been associated with cancer ${ }^{(29)}$.

In this study, two different immune parameters, namely serum immunoglobulins levels and lymphocyte subpopulations, were used to evaluate the immunotoxicity in waste incineration workers. The serum levels of IgG and IgM were found to be lower in waste incineration workers than in the controls, but without significant differences. In fact, there are many studies investigated the immunotoxicity among waste incineration workers; the results of some of these studies are consistent with the results of the present study; where, serum immunoglobulins and cytokines were not proven to differ significantly between waste incineration workers and their controls (7).
Moreover, in coke oven workers exposed to PAHs, serum immunoglobulin levels were lower in the exposed group than in the controls but without significant difference ${ }^{(30)}$. While, in other studies serum IgG levels decreased significantly with increased plasma concentrations of 2,3,7,8tetrachlorodibenzo-p-dioxin (TCDD) in a random sample of a population exposed to dioxins in the highly exposed zones; however, serum $\operatorname{IgM}$ and $\operatorname{IgA}$ concentrations did not exhibit any significant association with plasma levels of TCDD ${ }^{(31,32)}$. In contrast to the results of the present study, many researchers ${ }^{(33,34)}$ revealed significant reduction in serum levels of $\mathrm{IgG}$ and IgM among waste incineration workers compared to the controls; and attributed their results to the different chemicals emitted from waste incineration that could affect both humoral and cellular immune systems such as nitrous oxides, ozone, polychlorinated biphenyls (PCBs), benzene, and dioxins. Also, polycyclic aromatic hydrocarbons (PAHs) have been found to be potent immunosuppressants affecting humoral immunity, cell mediated immunity, and host resistance ${ }^{(35)}$. Moreover, heavy metals at high concentrations were found to have immunosuppressive effects; however at lower concentrations, the immunoenhancement is often observed ${ }^{(36)}$. 
In this study, there was significant increase in both $\mathrm{CD}_{8}$ ( $\mathrm{T}$ - suppressors) and $\mathrm{CD}_{25}$ expression and a significant decrease in $\mathrm{CD}_{4} / \mathrm{CD}_{8}$ ratio among waste incineration workers compared to the controls; while, there were no significant differences between both groups of workers regarding $\mathrm{CD}_{3}$ and $\mathrm{CD}_{4+}$ cells, suggesting that exposure to waste incineration products can suppress the immune responses and enhance the activation of $\mathrm{CD}_{8}+\mathrm{T}$ cells. Also, in a study conducted on a random sample of population exposed to TCDD, $\mathrm{CD}_{3}$ and $\mathrm{CD}_{4}$ concentrations did not exhibit any consistent association with TCDD plasma levels ${ }^{(37)}$. However, in another study conducted on workers exposed to high concentrations of TCDD in chemical plants, no significant differences were detected in the proportion of $\mathrm{CD}_{4+}, \mathrm{CD}_{8+}$ lymphocytes, $\mathrm{CD}_{16+}$ natural killer cells, and $\mathrm{CD}_{19} \mathrm{~B}$ lymphocytes among the exposed workers compared to the controls. ${ }^{(38)}$. These controversy in the results may be attributed to exposure to different toxic compounds and different levels of exposure at each work place $^{(7)}$.

In this study, the general characteristics of semen; including volume, sperm count, sperm motility, and the percentage of abnormal forms of sperms were evaluated in some waste incineration workers and controls. The sperms count and motility were found to be significantly reduced in waste incineration workers than in the controls. Moreover, the percentage of abnormal forms of sperms was significantly increased among waste incineration workers compared to the controls. In fact, the results of other studies about the reproductive disorders due to exposure to different waste incineration emissions were found to be controversial. Some researchers reported that, exposure to TCDD in waste incineration workers can induce severe reproductive and developmental problems

${ }^{(37)}$. Also, in other studies conducted on residents around incinerators, there was significantly increased risk of lethal congenital anomalies and birth defects $(39,40)$, multiple birth ${ }^{(41)}$, and a higher proportion of female births ${ }^{(42)}$. While in other studies, no association was found between residence near municipal solid waste incinerators and congenital anomalies, birth outcomes, and female births $(43,44,45,46)$.

In the present study, DNA damage was determined in the mononuclear peripheral blood cells of the studied workers; where there was significant increase in the number of dicentric chromosomes (dic) and accentric fragments (ace) among waste incineration workers compared to the controls. Similar findings were published by other 
researchers, who revealed significant differences between waste incineration workers and the controls regarding chromosomal aberrations $(10,47)$. Moreover, DNA damage in $\mathrm{T}$ - and B- lymphocytes and granulocytes was observed among waste incineration workers, which was attributed to PAHs exposure ${ }^{(48,49,50)}$. Also, an increased risk of cancer was observed among waste incinerator workers and residents close to waste incinerators ${ }^{(51) .}$ In the same way, it was found that, there was a significant association between $\mathrm{PAH}-$ DNA adducts in the peripheral mononuclear cells and breast cancer development

${ }^{(52)}$. Moreover, environmental exposure of children (indoor and outdoor) to PAHs and heavy metals as lead was found to induce cytogenetic effects such as, increased urinary mutagens, DNA adducts, micronuclei, and sister chromatid exchange in the peripheral lymphocytes ${ }^{(53)}$. In the contrary, in a study conducted on traffic policemen exposed to benzene and other aromatic hydrocarbons, no significant difference were detected in the frequency of sister chromatid exchange (SCE) in peripheral lymphocytes as well as in chromosomal aberrations in mononuclear blood cells between traffic policemen and their controls ${ }^{(54)}$. This controversy could be attributed to exposure to different toxic com- pounds and different levels of exposure at each work place ${ }^{(7)}$.

In this study, smoking was found to have no significant effect $(\mathrm{P}>0.05)$ on the results of cytogenetic analysis of waste incineration workers; where $(57.1 \%)$ of workers with chromosomal aberrations were smokers, while $62.9 \%$ of workers without chromosomal aberrations were also smokers. This result passes in parallel with the result of similar study, which was carried out in two waste disposal sites ${ }^{(10)}$. This finding could be attributed to low pack years of smoking among the incineration workers and strongly suggested that occupational exposure to different waste incineration emissions is quite enough for inducing cytogentic damage.

On the other hand, workers with chromosomal aberrations had significantly longer duration of employment $(9.6 \pm 0.37$ Y) when compared to those without chromosomal aberrations $(8.4 \pm 0.97 \quad \mathrm{Y})$ $(\mathrm{P}<0.05)$. This finding could be due to many of the emitted chemicals are known to be persistent, bioaccumulative, and mutagenic ${ }^{(6)}$. In the contrary, the duration of employment didn't influence the frequency of chromosomal aberrations significantly in waste incineration workers ${ }^{(10)}$. This disagreement could be attributed to shorter duration of employment in the other study $(5.1+3.5 \mathrm{Y})$. 


\section{Conclusion}

Unprotected occupational exposure to waste incineration emissions can cause serious immunological, reproductive, and, DNA changes (chromosomal aberrations). Moreover, waste incineration workers had significantly elevated blood lead levels compared to the controls. Also, the average concentration of the respirable particulate matter in the open dump and waste incineration area exceeded its threshold limit value.

\section{Recommendations}

A well designed control program is recommended; which should include the followings:

1-Avoiding open burning of waste products and promote the use of non- incineration treatment technologies.

2-Using incinerators equipped with proper emission control system.

3-Continous environmental and biological monitoring, for particulate matter, lead, and other hazardous substances.

4-Using immune system parameters, semen quality, and cytogentic studies as biomarkers of effect in such workers.

5-Wearing suitable protective equipment during work must also be mandatory.

\section{Acknowledgment}

We wish to thank the managers of the plants, especially Mr. Adel Kamhawy and E. Saied El-batawy, as well as all workers for their cooperation and understanding.

\section{References}

1-Alba N., Gasso S., Lacort T. and Baldasano J.M. (1997): Characterization of municipal solid waste incineration residues from facilities with different air pollution control system. J. Air waste manage. Assoc.; 47:1170-1179.

2-Franchini M., Rial M., Buiatti E. and Bianch F. (2004): Health effects of exposure to waste incinerator emissions: a review of epidemiological studies. An Ist Super Samita; 40 (1): 101-115.

3-Everaet K. and Baeyens J. (2002): The formation and emission of dioxins on large scale thermal processes. Chemosphere; 46: 434-448.

4-Brandt H.C. and Watson W.P. (2003): Monitoring human occupational and environmental exposures to polycyclic aromatic compounds. Ann. Occup. Hyg. J.; 47:349-378.

5-La Dou J. (1990): Environmental Health, hazardous waste management. In: La Dou J. (ed.): Occupational Medicine, 1st edition. Prentice Hall International. Chap. 39; pp: 526-531.

6-Johnson B.1. (1999): Impact of hazardous waste on human health. US: CRC Press.

7-Oh E., Lee E., Im H. et al., (2005): Evaluation of immuno and reproductive toxicities and association between immunotoxicological and genotoxicological parameters in waste incineration workers. Toxicology J.; 210: 65-80.

8-The International Agency for Research on Cancer (IARC) (1998): Monographs on the evaluation of the carcinogenic risk of chemicals on hu- 
mans, Polynuclear Aromatic Compounds, Part 1, Chemical, Environmental, and Experimental Data: 32.

9-Hulpke H., Koch H.A. and Wagner R. (1993): ROMPP Lexikon Um welt Verlag, StuHgart, NEW YORK (Abstract); 181-184.

10-Fender G. and Wolf G. (1998): Cytogenetic among waste incineration workers. Toxicology letters; 97,98:149-154.

11-Salvaggio J.E. and Sullivan K.A. (1998): The immune system and the environment. In: Rom W.N. (ed.): Environmental and Occupational Medicine, 3rd edition. Lippincott-Raven Publishers. Chap. 9; pp: 87-108.

12-Mckinnon R.A. and Nebert D.W. (1998): Environmental Mutagenesis. In: Rom W.N. (ed.): Environmental and Occupational Medicine, 3rd edition. Lippincott-Raven Publishers. Chap. 15; pp: 187-194.

13- Schaller K.H. (1996): Selected metals. In: WHO, Biological monitoring of chemical exposure in the work place guidelines. Vol 1. Chap. 3; pp: 112-126.

14-Biamchi A.T., Moonen-Peusen H.W. and Von Der Hei Den P.J. (1995): The use of double antibody Sandwich Elisa and monoclonal antibodies for the assessment of Procaine IgM, IgG, and IgA concentration. Vet. Immun. of Immunopath.; 44: 307-317.

15-Karakaya B.Y. Turhan A., Erdem O. et al., (1999): Investigation of some immunological functions in a group of asphalt workers exposed to polycyclic aromatic hydrocarbons. Toxicology; 135: 43-47.

16-Natarajan A.T., Boei J.J., Darroudi F. et al., (1996): Current cytogentic methods for deticting exposure and effects of mutagens and carcinogens. Environ. Health Prespect.; 104: 445-447.
17-Guzick D.S., Overstreet J.W., Factor-Litvak P. et al., (2001): Sperm morphology, motility, and concentration in fertile and infertile men. N. Engl. J. Med.; 345 (19):1388-1393.

18-Norsus M. (1997): Statistical Package for Social Science (SPSS) base 9.0 for windows users guide. Chicago, IL: SPSS.

19-Abanades S., Flamant G., Gagnepain B. and Gauthier D. (2002): Fate of heavy metals during municipal solid waste incineration. Waste Manage. Res.; 20:55-68.

20-Whetley A.D. and Aadhra (2004): Polycyclic aromatic hydrocarbons in solid residues from waste incineration. Chemosphere; 55: 743-749.

21-Oh J.E., Choi S.D., Lee S.J. and Chang Y.S. (2006): Influence of a municipal solid waste incinerator on ambient air and soil PCDD/Fs levels. Chemosphere; 64(4): 579-87.

22-Zakaria A.M., Labib O.A., Mohamed M.G. et al., (2005): Assessment of combustion products of medical waste incineration in Alexandria. $\mathbf{J}$. Egypt Public Health Associ.; 80 (3-4): 405-431.

23-Grant S. (1989): Dust control in industry. In: Parmeggiani L. (ed.): Encyclopedia of Occupational Health and Safety, 3rd edition. Geneva: ILO; Vol. 1; pp: 685-688.

24-Feng S., Wang X., Wei G. et al., (2007): Leachates of municipal solid waste incineration bottom ash from Macao: Heavy metal concentrations and genotoxicity. Chemosphere; 67 (6): 1133-1137.

25-Blasiak W.K. (2003): In vitro genotoxicity of lead acetate: induction of single and double DNA strand breaks and DNA-protein cross-link. Mutat. Res.; 535 (2): 127-132.

26-Bonde J.P., Joffe M., Apostoli P. et al., (2002): Sperm count and chromatin structure in men exposed to inorganic lead: lowest adverse levels. Occup. Environ. Med.; 59 (4): 234-242. 
27-Malkin R., Brandt-Rauf, Graziano J. and Parides M. (1992): Blood lead level among incinerator workers. Environ. Res.; 59: 265-270.

28-Saryan L.A. and Zenz C. (1994): Lead and its compounds. In: Zenz C., Dickerson B. O. and Horvath E.P. (eds.): Occupational Medicine, 3rd edition. Mosby Publisher. Chap.18; pp: 506541.

29-Silbergeld E.K. (1990): Implications of new data on lead toxicity for managing and preventing exposure. Environ. Health Perspect. ; 89 : 49-54.

30-Winker N., Tuschi H., Kova R. and Weber E. (1996): Investigations in a group of workers exposed to various levels of polycyclic aromatic hydrocarbons. J. Appl. Toxicol. ; 17 : 23-29.

31-Neubert R., Maskow L., Triebig G. et al., (2000): Chlorinated dibenzo-p-dioxins and dibenzofurans and the human immune system: Plasma immunoglobulins and cytokines of workers with quantified moderately increased body burden. Life Sci.; 66(22):2123-2142.

32-Baccarelli A., Mocarelli P., Patterson D.G. et al., (2002): Immunologic effects of dioxin: new result from Seveso and comparison with other studies. Environ. Health Perspect.; 116:11691173.

33-Holsapple M.P. (1995): Immunotoxicity of halogenated aromatic hydrocarbons. CRC Press 2nd edition: 257-297.

34-Burns L.A., Meade J. and Munson A.E. (1996): Toxic responses of the immune system. In: Casarett and Doull's Toxicology : The basic science of poisons, 5th edition. New York: McGraw Hill; pp: 355-402.

35-Ward E.C., Murray M.J. and Dean J.H. (1995): Immunotoxicity of non-halogenated polycyclic aromatic hydrocarbons. In: Dean J.H., Luster
M.J., Munson A.E. and Amos H. (eds.): Immunotoxicity and Immuno-pharmacology, 1st edition. New York: Raven Press; pp: 291-303.

36-Koler L.D. (1980): Immunotoxicology of heavy metals. INT. J. Immunopharmacol.; 2:269-279.

37-Kang M.J., Lee D.Y., Joo W.A. and Kim C.W. (2005): Plasma protein level changes in waste incineration workers exposed to 2,3,7,8tetrachlorodibenzo-p-dioxin. J. Proteome. Res.; 4(4): 1248-55.

38-Ernst M., Flesch- Janys D., Morgenstern I. and Manz A. (1998): Immune cell functions in industrial workers after exposure to $2,3,7,8$ tetrachlorodibenzo-p-dioxin:dissociation of antigen specific T-cell responses in cultures of diluted whole blood and of isolated peripheral blood mononuclear cells. Environ. Health Prospect.; 106:701-705.

39-Tusscher G.W., Stam G.A. and Koppe J.G. (2000): Open chemical combustions resulting in a local increased incidence of oro-facial Clefts. Chemosphere; 40:1263-1270.

40-Dummer T.J., Dickinson H.O. and Parker L. (2003): Adverse pregnancy outcomes around incinerators and crematoriums in North West England, 1956-1993. J. Epidemiol. Community Health; 57(6): 456-461.

41-LIoyd O.L., Lloyd M.M., Williams F.L. and Lawson A.B. (1988): Twinning in human populations and in cattle exposed to air pollution from incinerators. Br. J. Ind. Med.; 45:556-560.

42-Williams F.L., Lawson A.B. and Lloyd O.L. (1992): Low sex ratios of births in areas at risk from air pollution from incinerators, shown by geographical analysis and 3- dimensional mapping. Int. J. Epid.; 21:311-319.

43-Cresswell P.A., Scott J.E., Pattenden S. and Vrijheid M. (2003): Risk of congenital anomalies 
near Tge Byker waste combustion plant. J. Public Health Med.; 25(3): 237-242.

44-Cordier S., Chevrier .C. Robert-Gnansia E. et al., (2004): Risk of congenital anomalies in the vicinity of municipal solid waste incinerators. Occup. Environ. Med. J.; 61(1): 8-15.

45-Tango T., Fujita T., Tanihata T. et al., (2004): Risk of adverse reproductive outcomes associated with proximity to municipal solid waste incinerators with high dioxin emission levels in Japan. J. Epidemiol.; 14(3): 83-93.

46-Lin C.M., Li C.Y. and Mao I.F. (2006): Birth outcomes of infants born in areas with elevated ambient exposure to incinerator generated PCDD/Fs. Environ. Int.; 32(5): 624-629.

47-Gonsebatt M.E., Salazar A.M., Montero R. et al., (1995): Genotoxic monitoring of workers at a hazardous waste disposal site in Mexico. Environ. Health Perspect.; 103(supple. I) 111-113.

48-Lee J., Kang D., Lee K.H. et al., (2002): Influence of GSTM1 genotype on association between aromatic DNA adducts and urinary PAH metabolites in incineration workers. Mutat. Res.; 514 (1-2): 213-221.

49-SUL D., oh E., IM H. et al., (2003): DNA damage in T- and B- Lymphocytes and granulocytes in emission inspection and incineration workers exposed to polycyclic aromatic hydrocarbons, Mutat. Res.; 6: 175-191.
50-Marczynski B., Preuss R., Mensing T. et al., (2005): Genotoxic risk assessment in white blood cells of occupationally exposed workers before and after alteration of the polycyclic aromatic hydrocarbon (PAH) profile in the production material: comparison with PAH air and urinary metabolite levels. Int. Arch. Occup. Environ. Health; 78 (2): 97-108.

51-Comba P., Ascolli V., Belli S. et al., (2003): Risk of soft tissue sarcomas and residence in the neighborhood of an incinerator of industrial wastes. Occup. Environ. Med. J.; 60: 1-4.

52-Gammon M.D., Sagiv S.K., Eng S.M et al., (2004): Polycyclic aromatic hydrocarbon-DNA adducts and breast cancer: a pooled analysis. Arch Environ Health ; 59(12) : 640-649.

53-Mielzynska D., Siwinska E., Kapka L. et al., (2006): The influence of environmental exposure to complex mixtures including PAHs and lead on genetic effects in children living in Upper Silesia, Poland. Mutagenesis; 21(5):295304.

54-Carere A., Andreoli C., Galati R et al., (2002): Biomonitoring of exposure to urban air pollutants: analysis of sister chromatid exchanges and DNA lesions in peripheral lymphocytes of traffic policemen. Mutat. Res.; 518(2): 215-224. 